\title{
PRODUCTION TECHNOLOGY AND COMPETITIVENESS IN THE HUNGARIAN MANUFACTURING INDUSTRY*
}

\author{
A. ARTNER \\ (Received: 17 November 2004; revision received: 11 April 2005; \\ accepted: 13 May 2005)
}

Following the big transformations of the 1990 s, enterprise structure and technological level seem to have become stabilised in Hungary. Under these circumstances it is especially interesting to identify the elements responsible for competitiveness in general, and the role technology plays in development in particular, according to managers experienced in production and marketing. This empirical study - based on in-depth interviews and field research - summarises characteristics of the technological level in the sectors examined, role of technology and labour in production, effects of foreign direct investment, relations between competition and firm-level factors determining competitiveness, and concludes by summing up those most frequently mentioned proposals that should be incorporated into economic policy according to managers. Main findings indicate that more qualified, more intensive and cheaper labour can be substituted for high technology. The competitiveness of an enterprise is not determined by technology alone, but rather by a combination of technology, the parameters of available labour and the costs of investment increasing productivity. The insufficiency of inter-company relations, together with a shortage of available assets necessary for investment constitute the major threat undermining the competitiveness of enterprises in present-day Hungary.

Keywords: technology transfer, competitiveness, human capital, skill, R\&D, investment policy

JEL classification index: D24, J24, L22, P12

\section{INTRODUCTION}

Although Adam Smith laid the foundation of modern political economics by field research (showing the division of labour through the example of needle production), economists mainly prefer mathematical models and statistical analyses, while relatively few of them seek opportunities of direct experience - albeit theory

* The research was carried out within the framework of a larger project entitled "Strengthening Economic Competitiveness" in the Institute for World Economy of the Hungarian Academy of Sciences, commissioned by the Prime Minister's Office.

Correspondence: A. Artner, Institute for World Economics, Hungarian Academy of Sciences, Országház u. 30, H-1014 Budapest, Hungary. E-mail: aartner@vki.hu 
can hold only if exposed to the permanent test of experience. However, experience is an essential means also of getting to know the changes, new aspects, obstacles and aspirations, while it is often almost the sole source of exploring some special characteristics of production.

As the quintessence of his study, based on experiences of economists excellent in empirical research, summarising the limits, opportunities and possibilities of widening the methods of field research, Helper (2000) emphasises that field research can serve as a starting point, and even a direct source of economic theories.

The reader is holding a summary of an empirical research based on a field research in his/her hand. By means of in-depth company interviews we were looking for answers to the questions: What is the relationship between the technological level of enterprises in Hungary and their competitiveness? What kind of economic policy could contribute most to the growth of competitiveness? In order to collect sufficient information, we interviewed 25 manufacturing companies and 6 industry associations representing the interest of 5 industries: confectionery, garment, car spare-parts, test and measuring instruments, and castings. When selecting the industrial branches, our guiding principles were that (1) both "leading" industries and those "lagging behind" in technology should be represented in the sample, (2) both technology- and labour-intensive manufacturing industries should be included, and (3) branches integrated by TNCs should be represented, as well as the ones having greater independence.

All together 31 interviews were made by the author, a minimum of 5 interviews in each industrial branch. She also visited twelve factories in order to gain first-hand experience about the manufacturing process in all the branches studied. Industrial branch summaries were assembled based on the interviews and company case studies. The current situation and problems outlined by the 31 managers boasting with considerable professional, managerial knowledge and experiences point far beyond pure empiricism incorporating the possibility of uniqueness. The most important lesson of the research is that many identical principles and proposals arose from the various interviews, regardless of industrial branch, enterprise size, or extent of success.

Of course, there are sectoral and enterprise (product) specialities. However, in an interesting way the order of principle is the same: the criteria for the company's competitiveness are identical even if the conditions for creating them in the given branch or in the given enterprise are more or less different.

In the last decade quite a few company surveys (questionnaires or interviews) have been conducted in this topic in Hungary, such as e.g. Szalavetz (2000), Ministry of Education (2000), Harsányi et al. (2001), Hamar (2004) or Chikán et al. (2004). Especially the latter study bears a lot of similarities to our results: managers' expectations of a stable monetary policy, their perception of taxes and fees, 
the overruling ambition for cost-effectiveness (rather than for technological upgrading in itself), the opinion that the biggest impediment to innovation is the lack of sufficient financial resources, just to mention a few of the common findings.

\section{MAIN CHARACTERISTICS AND VALIDITY OF THE SAMPLE}

In the sample the number of employees of the enterprises examined ranged from 2 to 1700 , while their annual turnover was between 168 million and 14 billion HUF. Out of the 25 enterprises 5 is small (employs less than 50 persons), 10 is medium (from 50 to 250 employees) and 10 is large (over 250 persons). The ownership structure is as follows: 16 Hungarian, 7 foreign, 2 mixed. The total number of employees in the 5 branches examined might range from 160,000 to 170,000 persons (based on the estimation of the industry associations, which is hampered by voluntary data reporting and inconsequent sectoral classification).

The share of export varies in the enterprises examined, ranging from $25 \%$ to $100 \%$. The value added is usually around $30 \%$, it is $50-60 \%$ in the testing and measuring instrument industry, but in case of certain innovative products of high software content it may reach $90 \%$. The financial situation of the enterprises range from loss to a gain of $7-10 \%$ and in case of certain products it is extremely high (50-55\%, in case of own marketing even $80-85 \%)$. The financial situation of several firms currently showing a deficit or merely a small profit was much better at the end of the 90 s.

Gross production of the five sub-branches investigated (confectionery, garment, car spare-parts, testing and measuring instruments, castings) represents 9-10\% of the Hungarian manufacturing industry. The sample companies produce circa 80 billion HUF and employ more than 9000 people in total. This means that their activity accounts for $6-7 \%$ of the sub-branches' production and $0.6-0.7 \%$ of the Hungarian manufacturing output and employment. If we take only companies with more than 4 employees into consideration, the share of our sample is $1.1 \%$ in Hungarian manufacturing.

As far as geographical structure is concerned, the majority of sample companies and their factories are located in or around Budapest, this region being heavily overrepresented compared to the national geographical structure of Hungarian manufacturing. This is the case for south-east Hungary $(20 \%$ of the factories surveyed), too. In the sample, $10-13 \%$ of the factories are located in northeast and north-west Hungary, which is about the national average, while southwest Hungary with only one factory is heavily underrepresented.

To sum it up, the sample primarily represents medium- and large-scale, Hungarian-owned companies, located in the more industrialised subregions of Hun- 
gary. This fact may show the possible relevance of our investigation for researchers and also for economic policymakers in our globalising world: the endeavours and difficulties in modernising production technology and competitiveness in a segment of the Hungarian industry, which could serve as the engine of employment-generating development.

\section{THE TECHNOLOGICAL LEVEL OF PRODUCTION}

\subsection{The technological features of the sectors}

Based on the research, the estimated average life of the machines used in the sectors is 10-20 years, but differences are rather large both between firms and inside enterprises. Almost everywhere either quite new machines, or 2- to 3-year-old ones can be found, but machines that are 30 (maybe 40-60) years old can frequently be seen as well. However, the age of the machine is not always decisive! For example, a mechanical pressing machine - with proper maintenance - can completely fulfil its function even if it is 60 years old. Old machines can be upgraded with certain accessories (e.g. conveyor) or with minor modernisations; what is more, with new electronics old machines may be improved even to a state-of-the-art level (e.g. turning or milling machines).

In comparison to the EU level, the enterprises estimated their own technology at 3 on a five-grade scale, on the average. However, the average value does not say much here, either. The scores range from 2 to 5 (or, in a few cases, the interviewees would rate their technology as more advanced than the technology available on the European market). The backwardness is greater in production technology than in development, where the instruments (testing and measuring instrument industry) represent top level (score 4 or 5). In agreement with this finding, backwardness relative to the EU top level amounts to about 10 years on the average (varying between 20 years of disadvantage and 5 years advantage). It appears from the answers that each mark represents 5 years, implying that technology renews at such intervals on the world market.

Compared to the peripheral countries of the EU, technology level is generally evaluated to be one score higher, i.e. at score 4 (deviation 3-5, or above) the backwardness is usually 5 years. In comparison to Eastern Europe, the firms gave score 4 or better to their own technology and in all sectors we can find enterprises putting themselves above the Eastern European level. At the same time, several managers in several sectors pointed out that there was high-technology in the Eastern Europe, too, adding that in the given sector ex-socialist manufacturers - not independently of nearly located Western productive capital - are "catching up" in 
terms of both technological level and competitiveness of products (quality, delivery time, etc.). Nevertheless, it seems that the majority of the Hungarian managers neglect the development in Eastern Europe. It seems as if their present successes and seemingly safe markets made them less cautious concerning potential competition from Eastern market players.

To sum it up, the examined manufacturing firms are characterised by medium technological level. At the same time, the instruments of production show a mixed picture, which is generally characteristic of the world market as well. This technological level and structure meets the small-scale, special or unique product pattern characteristic of all sectors requiring more living labour compared to mass production.

\subsection{Investment policy}

The figure given for the rate of investment to turnover ranges from 3 to $10 \%$, but characteristically it remains below $4-5 \%$. The rate fluctuates year by year. It is a characteristic feature of each sector and firm that investments follow short-term market demands. That is to say, investment is "only a compulsion", driven by customers' evolving demands and changing marketing conditions. Investments of great value and extension (e.g. building a new workshop) are made on very rare occasions, only in case of abundance of current assets (cheap parent-company credit), otherwise investments are always triggered by a specific order for a stable market. Consequently there are no medium- or long-term investment plans; investment is a part of fulfilling "the daily task". As for the machinery and fixed assets, mainly maintenance or "partial modernisation" (overhaul of old machinery), and, to a smaller extent, replacement is carried out.

Borrowing, rent and operational lease play an important role in investment. Borrowing the means of production (sometimes "free of charge", or rather on the basis of reciprocity according to circumstances) is more frequent in case of smaller firms. On the other hand, in the developed market economies big enterprises take the opportunity of renting, especially in case of means of transport. (According to Meinen and Verlinden (1997), renting or leasing costs constitute $20-40 \%$ of investments made for export deliveries in the Dutch manufacturing industry.)

Consequently, competition requires the permanent modernisation of technology, but this is not identical to a compulsion to introduce current high technology. Quality may be strongly improved and the unit cost may be significantly reduced by means of reorganisation, expansion, rent and lease of machinery, etc. It is also 
worth buying less modern technology, because with some modernisation and by running it in three shifts (!), competitiveness can be achieved.

Indeed, efficient (large capacity) technologies are to a certain extent in contradiction with the flexibility and competitiveness required by the market. New technology systems, automated machines are extremely expensive, return on investment is realised in several years (in some cases 10-15 years). Such a long time, however, is unforeseeable. For this reason in certain cases it is not worth spending money for the substantial replacement of the technology, even if funds are available. Investment is not only a matter of money and returns, but also of security (stable market).

Investments in themselves do not inform us about the capacities, if we do not know whether or not disinvestments were made at the same time. ${ }^{1}$ In our sample the fate of the machines sorted out as scrap varies even inside a sector. Sale, storing and - rarely - also destruction takes place. As to selling, various approaches are observable. Some are careful to prevent their competitors putting their hands on the machines, moreover, they avoid selling discarded machines to their subcontractors in order "not to damage quality" (car spare-parts industry). In other sectors, to comply with market conditions, old machines are sold to smaller enterprises in order to create subcontractors with the capacity to manufacture in case of capacity shortages resulting from certain orders, or boom (e.g. garment industry).

Summarising the above, investments are not motivated by the goal of raising productivity or managing the necessary labour, but rather by gaining market share and cost-saving, realisable also in many other ways. For this reason the investment policy of the examined enterprises is not planned, but "project-principled" everywhere. The lack of capital often halts this project-principled investment practice. In such a case enterprises borrow or buy used machines from each other (e.g. clothing industry).

\subsection{R\&D}

The role research and development plays in competitiveness is practically known in economic theory since Leontief's works. In addition to the subsequent development of this theory - mainly owing to Hughes' (1986) work and most of all on the basis of his model - since the 80s a lot of empirical researches have dealt with the strong correlation between R\&D and world market competitiveness measured by the ratio of export. As for the Finnish industry Vuori (1997) and in the case of the

1 On disinvestment see e.g. Smeets and van den Hove (1997) on the example of the Dutch industry.

Acta Oeconomica 55 (2005) 
Hungarian industry Török and Petz (1999) have demonstrated the export-promoting effect of R\&D specialisation, although - as they highlight - this correlation is not universal.

According to the field research of Szanyi (2002), during the transition the emphasis of R\&D activity at Hungarian enterprises has been shifted from basic and applied research to product development. By the end of the 90s, the initial processes of technological modernisation and product innovation slowed down, owing to its relation to foreign direct capital. Our research supports this statement. There is scarcely any example in Hungary for high-tech activity, basic and applied research and real innovation at the enterprise level at present. It is only partial product development and minor modification of technologies that are going on. Therefore, $R \& D$ is mainly limited to production and product development, $\mathrm{R} \& \mathrm{D}$ departments are rarely found, $R \& D$ intensity is very low.

Products tend to be developed in accordance with the existing technology. Moreover, technological solutions and investments are determined by the ordered (or newly developed) products. Development of production is carried out typically only if it is required by the product. It became evident from the interviews that in the end it is not the technology that counts, but the product. Technology is subordinated to the products and products are determined by the market (demand, customer, multinational owner). In our sample the only exception was the testing and measuring instrument industry, where innovation, i.e. the development of a new product "from scratch" is the key factor of staying on the market.

\section{THE ROLE OF TECHNOLOGY AND LIVING LABOUR IN PRODUCTION}

\subsection{The role of technology}

Technology is a factor of competitiveness. However, it was pointed out by all the companies without exception that using high technology is not the only way to assure competitiveness. All technology can be upgraded by more or less complementary modernisation. Technology, however, depends on the scale of production and products, too. From the point of view of technology, the world market is not homogeneous. Mass production needing the most up-to-date technology is the privilege of the biggest enterprises of the world market.

The age of machinery matters mainly because of the additional costs arising from failure and maintenance (stoppages and repairs), which have nothing to do with the price of a new machine. On the other hand, speed and quality can be increased and defect rate decreased by more automated technology, but living labour may also improve these indicators. For this reason, cost-reducing invest- 
ments can be substituted by living labour to a certain extent, which extent, of course, is determined by the characteristics of the product and the quality requirements.

The experiences gained by the enterprises support the following relationship: in the long run competitiveness can only be ensured by decreasing the ratio of living labour, i.e. by increasing productivity. Competitiveness means efficiency, i.e. low unit cost. However, reducing costs (cost/unit), or increasing efficiency (profit/total investment) are not identical to increasing productivity (unit/working hour) and these indicators do not go hand in hand. To increase productivity, only such an investment is worth carrying out which simultaneously reduces the (unit) costs. It is worth introducing the more up-to-date technology only if returns are quick, that is to say, if it is not too expensive, or more generally, if it saves more living labour than what it costs. The replacement of living labour with technology is always a question of rate of returns. The point, where investment in technology becomes inevitable is determined by calculating the relations between the price of labour and the maximum of work possible (amount, intensity), as well as the price of the more productive means of production. In other words, the question is whether the unit cost of production remains lower by keeping the present technology (and increasing the intensity, i.e. the amount of work), or by investing into new, more productive, automated technology (taking amortisation into account).

The above statement was expressed in a concentrated form by one of the subsidiary company managers of a multinational enterprise manufacturing car spare-parts: in addition to quality, "investment in technology reducing costs (automation)" is the most important factor of competitiveness. One of the experts at the labour-intensive garment sector, an industry where automation is difficult, underlined the difference between cost-reduction and productivity increase as follows: "it is not the machine, but the cost, including the wage that is the decisive factor".

The results of our research are in harmony with the correlation calculations of Buzás and Novák (2004), who found no provable relation between the productivity of an enterprise (technology) and profitability (rate of profit) in a significant part of the manufacturing sector in Hungary. The mixed technological level of the manufacturing industry in Hungary makes it possible to operate less automated technologies, lagging 5-10 years behind the technological level of the world market, in a competitive (profitable) way. This, however, involves the consequences that where living labour is substituted for more productive technology, the social worktime basis is wasted (it remains locked up in the production to a greater extent than necessary). 


\subsection{The role of labour force}

In some companies qualifications were considered unimportant ("no need for special qualifications of manpower") and they were on the opinion that skilled work cannot replace proper technology. However, the majority of managers interviewed thought that skilled and/or cheap labour could compensate for their companies' competitive disadvantage deriving from outdated technology, at least to a certain extent. (For example, the security of production cannot be maximised by living labour. In case of work done by humans, only a smaller defect rate can be ensured by (manual) control, while the automated machine makes no fault. Besides, manpower is unable to perform certain operations in the required quality, e.g. to sew "eye-form button-holes" in the garment sector.) What are behind the different opinions?

In case of highly automated production, less living labour, even less skilled work is needed. Where the technology is still incomplete, more living labour and more professional knowledge (skill) is necessary. Consequently, with the progress of automation, the importance of creativity and qualifications declines. However, this general tendency develops at a different rate both by sector and by enterprise. In labour-intensive sectors (e.g. garment industry) or in case of special products (e.g. certain measuring instruments) produced in small series, or handicraft, machinery cannot substitute for the living labour to such a degree as in mass-produced car spare-parts. Depending on the range of products and the development of the applied technology, the opinions about the role of living labour (skill) can be different as well.

Furthermore, the requirements of professional knowledge of product development and those of production must be separated from each other. Product development requires high qualifications, for example, in the domestic measuring equipment industry. Parallel with the progress of technology, labour is gradually squeezed out from production. Qualification of manpower and operation are here factors substituting each other. However, from the point of view of productivity, up-to-date technology cannot be replaced by labour above a certain limit. As for product development, qualifications and abundance of novel ideas are crucial, thus making the story somewhat different from that in production. However, as the automation of product development advances, experiences show a similar trend to that observable in production, though more slowly and to a smaller extent: sophisticated softwares, testing and measuring instruments are increasingly taking over the role of living labour and professional knowledge. (Quoting the manager of a development-oriented company: "the ratio of wage could be reduced by better softwares".) 
For this reason, properly skilled manpower is, partly and in inverse proportion to the applied technological level, able to substitute for technology and compensate for competitive disadvantage stemming from underdeveloped technology. However, the price at which this happens also has relevance. The price of labour and the substitution process of living labour by machinery - as said in the chapter about the role of technology - are in close connection. At present the price of Hungarian labour force is low enough so that on the basis of cost management it is usually not worth substituting it for a higher productivity solution. Our empirical study proves, however, that this situation results in additional work and an increase of labour intensity.

\subsection{Qualifications}

As pointed out already, together with living labour the role of skilled work also decreases as a consequence of the general technological tendency. However, considering the medium technological level of the Hungarian manufacturing industry, skilled labour is still of great importance.

Several managers stress the fact that the sole stable competitive advantage of the enterprises lies in the (still) existing professional knowledge and experience. This confirms our statements concerning the substitution of skilled work and technology. It was also frequently emphasised that capabilities of Hungarian skilled workers far surpass those of Western ones.

In contrast, the situation of vocational training, and the supply of skilled workers was severely criticised almost everywhere, and not any of the managers was satisfied with the present situation. The supply of qualified, innovative workers working in higher positions in the organisation is not guaranteed satisfactorily either. Only those companies failed to emphasise the deficiencies of the vocational/high level training where applied technology has already rendered the need for both skilled workers and professional knowledge secondary.

Enterprises know by experience that the lack of qualifications, as well as insufficient, or lacking practical/workshop education is an enormous problem, "those who work in the workshop know best where the shoe pinches". If skilled labour is able to replace (expensive) technology to a certain extent, it is understandable to what a high degree the lack of qualified manpower hampers the competitiveness of the enterprises in Hungary. 


\section{THE ROLE OF FOREIGN CAPITAL}

\subsection{Development of technology}

It is generally accepted that in the age of globalisation, in addition to the enterprises' own development efforts and the purchase of machinery or know-how (embodied technology), the technology-developing role of the spillover effects of foreign capital investment is increasing. However, the extent of the spillover is disputed. For example, Vuori (1997) emphasises that to make use of these effects, on top of the donors' development, special conditions are needed in the host country. These conditions are as follows: openness, capability for absorbing new technologies and adjusting them to their own requirements. Due to the fact that not every country disposes of these capabilities, the practical importance of international technological spillover lags behind its theoretical importance.

Investors' cost-optimalising strategy also contributes to the formulation of limits to the practical importance of the international technological spillover. This phenomenon may be illustrated by the example of the global sourcing strategy of FIAT, which tries to meet a double challenge according to Camuffo and Volpato (n.d. - p. 26). On the one hand, it tries to find subcontractors able to ensure a world-wide optimal combination of cost, quality and service, on the other hand, the company attempts to standardise each and every element of the given model at all production and assembly plants. If we give it a thought, it becomes evident that in this strategy, in addition to the possibility of spillover, an attitude of isolation with a neutral effect on technological development is also included. In other words, the investor relies mainly on and selects between the existing conditions of production.

The limitations of the influence of the foreign capital on the technological development were proved by Artner $(2000 ; 2004)$ and by Farkas $(2000)$ in the cases of Ireland and Hungary, respectively. At the same time, Hamar's (2004) empirical study covering five accession countries, among them Hungary, found an unambiguous influence of the inflow of direct capital investment on the technological catching-up, but in fact together with an extreme heterogeneity of the subsidiary companies.

According to our experiences gained at the enterprises examined, the direct and indirect influence of foreign direct capital investment on the technological development is limited, more or less accidental and depends strongly on the investor.

Foreign enterprises in Hungary give work to a great number of suppliers. At the same time, their location could be anywhere, they can delocate any time, making Hungary vulnerable. 
According to one of the interviewees who knows foreign investors well, the multinational companies came to Hungary because wages and costs of environmental protection are relatively low here. Consequently, they primarily chose to transfer not the high-tech, but rather their outdated technology to Hungary. However, this situation cannot be sustained in the long term, "since they want to realise the same returns here, as they do at home by operating their new machines". In addition, the tax and social securities burden of the Hungarian labour power are bigger than those of the neighbouring countries. Thus, the foreign company will either invest (modernise) or - if it is more profitable - delocate.

One of the managers of a multinational company admitted that Hungary's advantage lies in the fact that the number of working days are high, holidays are less and thanks to labour-market regulations "the manpower can be employed a more flexible way". Consequently, these factors make the utilisation of outdated technologies more profitable in Hungary.

This provides an explanation for huge technology imports that took place in the form of assets in kind (old machinery) mainly in the first half of the 90s. By now, the role of the reinvestment of profits has increased, but the relocation of the old machinery is still going on. Together with the foreign capital new means of production also arrived in our country in a number of cases, a part of them embodying high-tech equipment. This, however, is not a general phenomenon.

We have learnt from our interviewees that in certain cases the firm is subject to sale and purchase, but neither the old, nor the new owner is ready to transfer technology, or invest in new equipment. In these cases, at best, assistance is given to establish the integrated system of IT-management, which is the basic condition for communication and control. Generally, foreign owners aim to reduce requirements for living labour by reorganisations and automation that are accompanied also by increasing labour intensity almost everywhere. For instance, in one of the enterprises the output per worker increased by 72\% between 1993 and 2003 as a result of "rationalisations" (dismissals), instead of technological development. The same owner still believes that the workers are overpaid.

The experiences of the enterprises prove that foreign capital per se has no technological upgrading effect. As in the case of all forms of capital, the aim of the foreign capital is to realise profit. Only those owners invest in development that count on the profit-production capability of the affiliated company in the long run. Whether the investor is a professional, or a financial one was found not to influence development considerations. Though the financial investors are more inclined to look for solutions promising quicker profit, we also found counterexamples - both for professional investor's negligence, even "robbing" the company, and for a financial investor's insistence on development. 
If the foreign investor is simply a partner of the Hungarian company, it can still provide inspiration for the Hungarian company's development by intermediating the requirements of the world market. However, it would be a mistake to attribute these effects to "foreign capital". The point is merely that competition as it is, has a developmental effect: if I want to sell, I have to adapt to the requirements and to accept necessary alterations that promote sale figures.

\subsection{Other forms of modernisation effects}

Several companies in Hungary have learnt business management and working culture from their foreign owner or supplier. However, the foreign way does not necessarily imply a "better" way than the previous practice. It means, above all, the adoption of the methods of the company(-empire) practises on the world market. (Naturally, one has to accommodate to a new partnership characterised by a new owner, new customers, often new products. This situation requires adaptation mainly from the partner at the bottom of the hierarchy.) This hand-over and take-over basically takes place according to the foreign owners' ideas without consulting the partner, i.e. independently of the (admittedly good) local experts' opinion whether the change is rational (Hungarian experts often considered changes unadvisable). However, in the cases of the companies involved in our research there was no knowledge transfer at all. In all the sectors it was a general experience that foreign investors usually have nothing to add to the high level of expert knowledge and experience available in Hungary. This is the reason behind the quick and successful application of the newer technologies (machinery) as well.

Concerning foreign capital, Hungarian companies have extraordinary negative experiences, too. We have already mentioned the owner's general attitude of negligence, later passing the company into the hands of other firms. Moreover, small companies are at the mercy of the big ones in other ways as well. The requirements of the chain stores or the payment and contractual terms of the final product manufacturers are often disadvantageous for small firms. As a matter of fact, this phenomenon characterises the fierce competition between bigger and smaller companies (power of capital) rather than the relationship between foreign and Hungarian owned companies, i.e.: the capability of the bigger capitals for depriving the profit of the smaller capitals by means of their better position of power. This "vertical" cut-throat competition means limiting the competition and hindering the accumulation of capital of the smaller companies, namely their growth on the one hand, and promoting the concentration and centralisation of capital on the other. 


\section{COMPETITIVENESS}

Competitiveness, as well as the problems of the examined sectors fit into the general parameters of the existence of small- and medium-sized enterprises. As a consequence of the change of the regime in Hungary, big, integrated enterprises having market and capable of technological development have disappeared. In addition to that - as one of interviewees said - "the state did not help to make good use of the knowledge and the means of production in the new system, but actively took part in smashing vertical integrations".

These companies, left to their own devices, are currently trying to find their position on the market. In this endeavour they can rely on the means of production, expert knowledge and experience they control only to a certain extent. Due to the shortage of capital, however, these companies are unable to capture a firm market position alone. The reason is that the market segments (manufacturing small series and/or special, high quality products) that are still covered by them today are threatened to be narrowed by the competition of the cheap labour in Eastern European countries and also by big and technologically advanced enterprises, which dispose over complete manufacturing systems capable for small and special serial production.

\subsection{The competitive environment}

Today Hungarian companies compete on the world market. Domestic (national) competition takes place only in consumer goods (confectionery and garment industry, in our sample). There is competition both in manufacturing products and in supplier and subcontracting relations. Regarding subcontracting, the Eastern (and the Far-Eastern) competition, while for the component supply, the competition of the close and remote suppliers of multinational companies are on the rise. The relocation of the Western (Southern) suppliers of car-factories has also started towards Hungary, increasing competition and overshadowing the future of still booming Hungarian car-parts production.

Mechanisms determining substitution between technology and living labour have an effect on the allocation of capital, residing behind the above phenomenon. The development of the technology is only one of the elements of cost reduction. From the profit point of view, the less productive technology "can be revived" by using cheaper labour force. As the introduction of new technologies is justified by the relatively high wages of the developed countries, the less productive technologies are relocated towards further East. This phenomenon was firstly captured by 
Vernon (1966) in his product life-cycle theory. The technologies flow into cheap-labour countries in waves. Simultaneously, the market position of the independent manufacturers of the products made by these technologies is also changing. Hungary is in the middle of this process. For a time she can enjoy - at a different rate in each sector - the inflow and boom, then as competition sharpens, she will suffer from outflow.

The garment industry may serve as a typical example. By now, Hungarian SMEs know exactly that current trends foreshadow the relocation of the production to the East (to Romania, Ukraine), keeping only product development and perhaps logistics at home. Consequently, we can see the repetition of the same process we experienced with the inflow (and in many cases with the outflow as well) of the Western European garment producers. The question is: what will happen to employment? (In the garment industry 67,000, in the whole textile-garment-leather industry 170,000 people were employed in 2003.)

Contrary to this perspective, an alternative would be to build vertical integration ("verticums") coordinated by big organisations in all important industrial sectors. According to many managers, this is the only viable alternative for survival.

\subsection{The factors of competitiveness}

\subsubsection{Quality}

Concerning the sectors of manufacturing intermediary goods (castings, car-parts in our sample), it is necessary to clarify the widely spread opinion on the competition in quality: there is no competition in quality as such, the quality is a kind of "market admission fee". Those who are unable to produce in the required quality are ruled out of competition. The most important factor of competitiveness is price. And price competition is very intense.

Regarding the manufacturers of final goods (garment, confectionery and measuring instrument industry in our sample), the situation is a bit different. On the market of these products different qualities are available (the Hungarian industry belongs to the manufacturers of higher quality products), but here also, price is a key question of the competition at all levels of quality. On top of this, low price ensures a certain room for manoeuvre, which proves useful in cases when the buyers want the prices to be reduced, even at the expense of "something being taken out of the product" by the manufacturer. For the sake of a lower price, the buyers are ready to make a contract with the manufacturer of a less sophisticated product. In the sectors of special and innovative products such as, for example, the testing and 
measuring instrument industry, quality is represented by the product, by the innovation, or by specificity itself. This means that the quality is not decisive here either: it is the question of price and available capital whether the product is marketable.

\subsubsection{Costs}

Naturally, cost is a crucial factor determining price. The economic environment, the sectoral conditions, as well as the business strategy determine how the cost could be reduced in each sector and in each company. According to the conclusions of this research, the wage and - in certain sectors - energy costs constitute the biggest burden for the Hungarian manufacturing industry. Not only wages themselves, but also their additional costs are considered too high. This causes a headache especially for decision-makers in labour-intensive sectors (e.g. garment industry), but other sectors of the Hungarian manufacturing industry are also gravely affected. The reason is that Hungarian industry mainly consists of smalland medium-sized enterprises manufacturing non-serial, special products, their technology requiring more living labour than those of the top players of the world market even in sectors easier to be automated (producing bigger series, more standardised products).

The present structure of the Hungarian industry (i.e. a majority of small- and medium-sized enterprises) cannot be sustained for long, because technological development will sooner or later push them out of their present market segment. On the one hand, technology develops into a direction of combining the capability for mass production and special products, while on the other hand cheap labour manufacturers of mass production learn more and more of how to produce superior quality goods. The Hungarian industry consisting of "small" organisations compared to the world market has not, and will not have the capability - i.e. without an external help - to take advantage of mass production.

\subsubsection{Capital endowment}

The research has confirmed that capital endowment (current assets) is a decisive factor of competitiveness. Capital endowment determines the applicable price strategy (whether and to what extent the manufacturer can reduce the price when introducing the product), whether the company can finance marketing, whether it can sell its products directly or needs an intermediate, what terms of payment it can accept, whether it is capable of developing its own product or can execute sub- 
contracting only, etc. Thus, the implementation of cost-cutting investments depends on capital endowment, too. Price competition and the dictating position of bigger (buying, trading) enterprises hamper the accumulation of capital, so the shortage of working capital is a general and permanent problem even for companies employing more than 250 people, and it is a source of uncertainty of survival for smaller companies. Consequently, the condition of holding one's ground on the market is the (working) capital endowment, the capability for growth, which cannot - or on rare occasions can - be obtained in today's monopolistic market competition. This is a Catch-22 situation.

As we can see, the most important handicap of competitiveness for the Hungarian manufacturing industry is an enterprise structure characterised by the shortage of capital. The problem of the Hungarian industry is a general problem of small firms and the responsibility for this situation mainly lies in the disruption of production complexes at the time of the change of regime (i.e. blowing up the systems of vertical enterprise relations, as well as the negligence for rebuilding them).

\subsubsection{Technology}

Developed and unique technology is considered to be just one among the several factors of competitiveness by the managers interviewed. In the final analysis, it is not technology (productivity), but unit cost that really counts. The companies examined share the opinion that their technology is basically appropriate, suitable for producing competitive products. Every technology has got advantages and disadvantages, strong and weak sides. It is just the diversity of their technology, i.e. their capability for manufacturing many kinds of products which enable them to compete, often serving as the key factor to keeping their market position.

\subsubsection{Marketing}

If, besides the required quality, lowest price is the necessary condition, then marketing constitutes the sufficient condition of competitiveness. The latter is difficult to secure in case of companies provided with limited amounts of capital. Sectoral research carried out by Hernesniemi et al. (1996) in the Finnish economy (characterised by a company structure quite similar to the Hungarian one) found that - besides finance and knowledge of business strategy - marketing was the very function, which did not keep pace with the increase of the companies' technological level. This is a severe disadvantage in competitiveness, because without 
sufficient marketing technological knowledge cannot be successfully commercialised.

During the Hungarian research in all the sectors several people emphasised that competitiveness depends on marketing and gaining market share rather than on technology. The best product cannot be sold if customers do not get acquainted with it. Marketing is, however, expensive, so the majority of the companies cannot afford it to the satisfactory extent.

\subsubsection{Labour force}

Either based on a positive or on a negative experience, many interviewees pointed out that the loyalty of the labour force is also a factor of competitiveness. Based on our interviews, loyalty appears to be considered even more important than professional knowledge. (What is professional knowledge worth, if labour force does not work with absolute devotion?)

Managers try to promote identification with the company applying different forms of payment, based on performance. The question is whether "loyalty" gained in one way or another means a real identification with the interests of the privately owned company, or it reflects a mere compulsion stemming from employees' adherence to their jobs. This question is not an academic one, because it refers to identification with the work and in the end to the possible maximum of quantitative and qualitative productivity.

The price of labour means an ever increasing competitive disadvantage for the manufacturing industry in Hungary. The shortages of cheap labour stimulate the relocation of production, which, together with the process of cost management mentioned above and through unemployment and the decreasing demand for skilled work, results in the deterioration of the working conditions and the reduction of the wages in the long run.

\subsubsection{Company management}

Some of the interviewees brought up the issue of managers' mentality, since the ability of reacting quickly and adequately to market demands, proper company management (based on up-to-date management theories), as well as the structure of enterprises may also be regarded as factors influencing competitiveness.

Fujimoto (2001) pointed out the role of these factors discussing "organisational capability" which was able to counterbalance the decrease in international technological competitiveness of the Japanese car industry. This capability explains the

Acta Oeconomica 55 (2005) 
Japanese advantage ${ }^{2}$ in the "lead time" (LT). The organisational capability of the company may ensure market advantage even in case of a moderately intensive application of information technology. (This phenomena is called "IT-LT paradox".)

\subsubsection{Personal relations}

Many interviewees underlined that personal contacts have an outstanding importance in successful company start-up, sales, gaining market share and new partners. In the market competition price, as well as profit-making motives do play a decisive role, but in the often fierce and uncertain environment everybody is trying his best to eliminate uncertainties. Contrary to the public opinion, market actors are motivated by the profit relative to the risk, not by the "love of risk". They try to optimise the proportion of these two factors, i.e. to relatively minimise risk. Considering the fact that market relations are realised by people as well, trust-influencing the perception of risk - plays a central role in business negotiations.

Trust may be obtained in business relations, but under given circumstances by other means as well. Therefore, the successes of the management (maybe its "unjust" failures) are based on the scope and quality of their personal (economic, political) relations. Highlighting the dark side of this phenomenon, several managers complained about the contact-based, rather than truly professional evaluation process of tenders, or spoke frankly about "money distributed in advance" in case of state distribution of public funds.

\section{ECONOMIC-POLICY PROPOSALS - OPINION OF INTERVIEWEES}

Although managers came up with several explicit and implicit economic-policy proposals during our interviews, the general opinion reflected disappointment: nothing is expected (any more) from the economic policy.

Despite their general state of disillusionment, managers' suggestions and ideas are particularly valuable, not because of their novelty (the majority of the proposals is probably well-known by the leaders of the country), but because of the fact

2 Japanese automobile industry conventionally enjoys advantage in the product development lead time (period from exterior design approval to start of sales). Until the beginning of the 1990s Japanese car producers' average lead time was about 30 months, while US and European manufacturers reached only cca 40 months. Today the data are less then 20 versus 30 months, respectively. In this respect the competitiveness of Japanese car producers has increased, though, their position in the technological development has been deteriorated. This deterioration was counterbalanced partly by decreasing lead time.

Acta Oeconomica 55 (2005) 
that with the exception of a couple of specific ones, the majority of the proposals came up in all the sectors examined. The proposals reflect the most burning problems of the companies, so all of them are informative and worthwhile to be considered. For this reason we decided to report even those proposals which cannot be taken into consideration after careful economic-policy deliberation, according to market logic, or just because of EU rules, or the implementation of which would be the task of the companies under general circumstances, even if they are unable to do so.

Everywhere, almost without exception, the first expectation referred to the reliability of economic policy (exchange rate, trade policy and other regulations). Many people blamed the policymakers for having a rigid financial approach to economic policy and an administrative attitude towards development policy. They pointed out the need for a more flexible credit practice and cheaper credits, as well as the extension and conceptual revision of the state-funding system (e.g. stressing not only "fashionable" or "EU-issues").

In reference to the poor condition of roads, some people emphasised that primarily the state was responsible for developing the infrastructure. Others require an economic policy which carefully examines the situation, the role, developmental requirements of the sectors considered "lagging behind" and the far-reaching effects of their decline. Preparing impact assessment studies before policy decisions were also considered as highly necessary. There is a general discontent regarding the regulation of the black economy and firm measures are expected against the behaviours evading regulations and distorting the market. It is a general opinion that the legal system is not transparent and can be manipulated. Many persons referred to the often incomprehensible, unclear circumstances of accessing support (project funding), suggesting the possibility of corruption ("personal contacts"). The reduction of corporate tax (from 18 to 16\%) is generally considered an ineffective measure, unable to solve the shortage of working capital necessary for the investments.

The overwhelming majority of the companies in the sample would like to see an effective policy supporting small- and medium-sized enterprises. As cornerstones of this policy, orders by the state, extension of grants and aids and, in particular, increased efforts of export promotion and tax relief connected to development (!), increasing the limit of co-financing and rationalisation of the conditions were mentioned. Some additional points, for example promotion of participation in fairs and exhibitions, as well as maintaining trade representations abroad, supporting storage by means of public or semi-public organisations (since the system of "just-in-time" charges the suppliers with storage expenses) were also mentioned. 
Fitting into the criteria of Porter's diamond model, it was suggested that product development connected to joint projects of Hungarian suppliers and buyers should be supported, above all. The development of infrastructure could serve as a good example here. The multiplicator effect of foreign investors is increased mostly by involving a large number of suppliers. Far-Eastern investors are more inclined to do this because the relocation of their own suppliers here is still slow, but at the same time the $60 \%$ European content ratio must be met, too.

Local business tax (paid in proportion to turnover) hampers the establishment of regional (R\&D and logistic) centres, because their ratio of living labour is high. In order to eliminate our disadvantage in this respect, it would be more reasonable to apply local taxation on a profit basis, especially considering the fact that Hungary's neighbours (e.g. Slovakia, the Czech Republic) do not impose local business tax on firms at all.

Enterprises would like the government to support and improve vocational training, and make it more practice-oriented. In order to reach this goal, the majority of interviewees would be keen on offering the possibility of workshop practice. High energy prices not only damage competitiveness, but also directly hamper investments into environmental protection. According to big energy-consumers, the minimum solution would be payment in conformity with consumption, which makes the abolition of the current "bonded", "stand-by" fee necessary.

\section{The way out}

According to several interviewees, the actors of economic policy failed to elaborate and implement a long term strategy based on the analysis of the market processes in every sector. For instance, successful foundries nowadays export their products to Western car factories, where multinational companies re-export the original items as components to the car-part manufacturers in Hungary. As an expert of the foundry industry and, at the same time, a manager of a successful company pointed out: it would have been more rational and economical to integrate the domestic suppliers of the car industry, i.e. to build vertical integration ("verticum") under one integrator to avoid the detour of forwarding the components to domestic car-part manufacturers. The Hungarian industry would be stronger and the balance of trade would be better. The foundry industry delivers goods not only to car-part manufacturers but e.g. to railways, power stations and hydro stations, besides selling and buying as well. Apparently, this logic equally applies to other vertically organised sectors.

According to the majority of enterprises, an economic policy promoting vertical integration is badly needed. The desire for securing business partners - impor- 
tant to every company - is hidden behind this suggestion. Though this formulation may seem strange at the first glance, after decades of "big state-giants in socialism", looking into the matter closer the idea behind "building vertical integration" is very rational both from a technical-technological aspect and from the point of view of the market. The same proposal was worded by another study, also based on company interviews. Farkas and Mészáros (2002) found that due to the fact that no company can become viable without market (orders), the business background for small-and medium-sized enterprises might be secured by Hungarianowned big enterprises with suitable governmental assistance and support. The importance of the idea of "verticum" can be fitted into Porter's (1990) diamond model. In this model, one of the three factors determining the firm strategy and competitiveness is related and supporting industries, more exactly, new entrants emerging from them. Firstly, this emergence itself is often a product of vertical integration of these sectors. Secondly, the relation between the competitiveness of a firm and the sectors in question is not one-sided at all! A firm's long-term competitiveness is highly determined by the strategy it pursues in connection with related and supporting sectors: building partnerships can forestall emerging rivalry.

As for economic policy, it is not enough to develop only those places of production where profit is directly realised. After the emergence of the global networks of enterprises in the manufacturing industry, profit is realised more and more at the peak of the vertical set-up (at the final goods production), or better to say the final producer is able to withdraw value added (profit) from the lower levels of the production chain. Especially, in case small- and medium-sized enterprises have to face big customers. But only large enterprises provided with abundant capital can connect to the higher levels of the production chain. Though having large potentials, the Hungarian enterprises do not belong to this strong company sector.

Finally, economic policy must not lose sight of the general principle that the expenditure on micro level can be turned into income (thus paying off) or become a saving on macro level in a multiple way. For example, if we take into consideration the long list of harmful effects of unemployment (on health, social behaviour, mental and spiritual well-being, etc.), we find that social policy exercised through production (employment) is significantly cheaper in the long term than direct aid, distributed in the form of unemployment benefit. From the point of view of curing them, social diseases do not very much differ from the illnesses of the human body: in both cases the best solution is prevention. Not only for the government budget, but also for the whole society it is more economical to exercise the social policy (at least partly) "ex ante" or "preventively", than "ex post" in its independent, "clean" form. 


\section{REFERENCES}

Artner, A. (2000): A perifériáról a centrumba? Írország gazdasági fejlödése az elmúlt évtizedekben (From the Periphery to the Centre? Economic Development of Ireland in the Last Decades). Budapest: Aula Könykiadó.

Artner, A. (2004): Nemzetgazdasági versenyképesség és tőkevonzás - Írország példája (Competitiveness and Capital Attraction of a National Economy - Ireland's Example). Külgazdaság, 48(September): $58-75$.

Buzás, S. - Novák, Cs. (2004): A magyar feldolgozóipari vállalkozások nyereségességének meghatározói (Determinants of the Enterprise Profitability of the Hungarian Manufacturing Industry). Külgazdaság, 48(January): 28-41.

Camuffo, A. - Volpato, G. (n.d.): Global Sourcing in the Automotive Supply Chain: The Case of Fiat Auto "Project 178" World Car. International Motor Vehicle Program - MIT. Globalization Research, CA - Foiscari University of Venice, Italy, http://imvp.mit.edu/papers/0001/ cam-volp1.pdf

Chikán, A. - Czakó, E. - Zoltayné Paprika, Z. (eds) (2004): Fókuszban a verseny. Gyorsjelentés a 2004. évi kérdöives felmérés eredményeiröl (Competitiveness in Focus. Minute Sheet on the Results of the Questionnaire Survey in 2004). Budapest: Corvinus University, Competitiveness Research Centre, September.

Farkas, P. (2000): A külföldi működőtőke hatása a K+F-re és az innovációra Magyarországon (Impacts of the Foreign Direct Capital on the R\&D and Innovation in Hungary). In: A müködötöke kivitele és a technológiai fejlödés a 21. század közepén (Export of Foreign Direct Capital and the Technological Development in the Middle of the 21st Century). Budapest: Oktatási Minisztérium, 111-137.

Farkas, M. - Mészáros, T. (2002): A hazai magántulajdonú nagyvállalatok stratégiái (Strategies of Domestic Large-scale Private Companies). Vezetéstudomány, 33: 31-43.

Fujimoto, T. (2001): The Case for Cautious Optimism. Look Japan, May. http://www. lookjapan.com/LBecobiz/01MayEssay.htm

Hamar, J. (2004): Tőkevonzó-képességünk alakulása és a multinacionális cégek szerepe a magyar gazdaság technológiai és strukturális felzárkóztatásában (Changing of Our Capability of Capital-attraction and the Role of Multinational Companies in the Technological and Structural Catch-up of the Hungarian Economy). Külgazdaság, 48(May): 39-63.

Harsányi, L. - Nyers, J. - Soltész, J. (2001): A gazdaság technológiai színvonala és összetevői (The Technological Level of the Economy and its Determinants). Budapest: Oktatási Minisztérium.

Helper, S. (2000): Economists and Field Research: "You Can Observe a Lot Just by Watching". American Economic Review, May. http://www.nber.org/sloan/helper.html

Hernesniemi, H. - Lammi, M. - Yla-Antilla, P. (ed.: P. Rouvinen) (1996): Advantage Finland - The Future of Finnish Industries. ETLA - The Research Institute of the Finnish Economy. SITRA The Finnish National Fund for Research and Development. Helsinki: Taloustieto Oy.

Hughes, Kirsty (1986): Exports and Technology. London-New York: Cambridge University Press.

Központi Statisztikai Hivatal (Central Statistical Office). http://portal.ksh.hu

Meinen, G. - Verlinden, B. (1997): Statistics on Tangible Capital Stock. Direct Observation at Statistics Netherlands. Capital Stock Conference, Canberra, March 10-14, 1997.

Ministry of Education (2000): A vállalkozások technikai színvonala és korszerüsége 1995-1998 (The Technological Level of Companies' Physical Assets 1995-1998). Budapest.

Porter, M. E. (1990): The Competitive Advantage of Nations. New York: The Free Press, a Division of Macmillan.

Smeets, E. - van den Hove, N. (1997): Desinvestments. Capital Stock Conference, Canberra, March 10-14, Statistics Netherlands. http://www.oecd.org/dataoecd/9/2/2666852.pdf 
Szalavetz, A. (2000): Hagyományos iparágak - hanyatló iparágak (Traditional Industries - Declining Industries). Budapest: Oktatási Minisztérium.

Szanyi, M. (2002): Subcontracting and Outward Processing Trade as a Form of Networking in Hungary. Acta Oeconomica, 52(3): 347-370.

Török, Á. - Petz, R. (1999): Kísérlet a K+F-intenzitás és exportszerkezet közötti összefüggések vizsgálatára a magyar gazdaságban (Attempt for Examining the Correlation between the R\&D-intensity and the Structure of Exports in the Hungarian Economy). Közgazdasági Szemle, 46(March): 213-230.

Vernon, R. (1966): International Investments and International Trade in the Product Cycle. Quarterly Journal of Economics, May: 190-207.

Vuori, S. (1997): Technology Sources and Competitiveness. An Analysis of Finnish Industries. ETLA, The Research Institute of the Finnish Economy. Helsinki: Taloustieto Oy. 